Columbia Business School

CENTER ON JAPANESE CONOMYAND BUSINESS 日本经清经営研究所

Working Paper Series June 2009, No. 283

\title{
Industrial Concentration, Price-Cost Margins, and Innovation
}

\author{
David Flath
}

This paper is available online at www.gsb.columbia.edu/cjeb/research/ac

C OLUM BIA UNIVERSITY IN THE CITY OF NE W YORK 
May 12, 2009

\title{
INDUSTRIAL CONCENTRATION, PRICE-COST MARGINS, AND INNOVATION
}

\author{
David Flath*
}

abstract

This paper explores a panel data set matching establishment-based production statistics from Japan's Census of Manufacturers with wholesale price indices from the Bank of Japan, and Herfindahl indices from the Japan Fair Trade Commission. The data include annual observations over the period 1961-1990, for 74 industries at the 4-digit s.i.c. level. We estimate CobbDouglas production functions and Solow residuals for each industry and then use these estimates to further analyze the determinates of industrial concentration and innovation. The industries having great capital intensity, small employment of labor, and with high price-cost margins tend to be more concentrated. Cross-section estimates reveal a U-shaped mapping from concentration to innovation. JEL classifications L11, L13, L60, O30.

\author{
*David FLATH \\ Institute of Social and Economic Research \\ Osaka University \\ 6-1, Mihogaoka, Ibaraki \\ Osaka-fu 567-0047 \\ JAPAN \\ E-mail: flath@iser.osaka-u.ac.jp \\ tel. 81-(0)6-6879-9177
}




\section{INDUSTRIAL CONCENTRATION, PRICE-COST MARGINS, AND INNOVATION}

\section{Introduction}

This paper estimates the annual average rate of Hicks neutral technical change in 74 Japanese manufacturing industries, 1961-1990, and relates these estimates to industrial concentration and price-cost margins. We do this by first estimating Cobb-Douglas production functions, under the maintained assumption of constant returns to scale. The residuals from these regressions measure technical change, and the labor coefficients measure labor's share in total cost for each industry. Price-cost margins are computed as the percentage by which value added minus total cost exceeds value of shipments (where total cost is the wage bill divided by the Cobb-Douglas labor coefficient). We find that the industries having great capital intensity, small employment of labor, and with high price-cost margins tend to be more concentrated. Cross-section estimates reveal a U-shaped mapping from concentration to innovation.

The data are drawn on 4-digit s.i.c. industries, from Japan's Census of Manufacturers, for which wholesale price indices could be closely matched. These industries are defined as the sets of establishments - not firms- primarily producing like commodities. The close matching of the industries with corresponding wholesale price index categories affords a real output measure that is likely to be much more accurate than ones typically found in the empirical literature on production functions. That our data is observed at the industry level rather than the firm level poses aggregation issues which we do address. A strong point in the data set we examine is that, unlike firm-based micro-data, it allows us to precisely observe cross-industry variation at a fairly narrow (4-digit s.i.c.) level. Individual firms tend to be much more diversified than their constituent production establishments, and can often only be clearly assigned to industries at the 2-digit level. Yet the theories relating industrial competitiveness or industrial concentration to innovation seem much more applicable at the 4-digit level. Our data also include annual time series of Herfindahl index of industrial concentration, matched from yet another source, the Japan Fair Trade Commission which is the antitrust enforcement agency of Japan.

Because our panel data set matches establishment-based measures of factor inputs, wages, revenues and value-added with product-market observations on prices and industrial concentration, it affords a particularly clear look at the year-to-year co-movement in industrial 
concentration, pricing, and innovation for a wide set of manufactured goods, as well as supporting cross-industry analysis of the same variables.

\section{Basic Framework}

We begin by addressing the aggregation issue. We will only observe production data at the industry level, so we need to make assumptions about how the aggregate variables we observe are related to the firm-level variables we do not observe. The maintained hypothesis underlying our approach is constant returns to scale at the firm level.

Let us posit that each firm is constrained by a Cobb-Douglas production function with two inputs: labor and capital. Suppose further that the output elasticities of labor and capital are the same for all firms in the same industry, though total factor productivity may vary from firm to firm. Suppose also that firms in the same industry face the same factor prices and thus employ capital and labor in the same proportions to one another (We presume that all firms are equally adjusted to the same factor prices). Denote the production of firm $\mathrm{f}$ by

$$
\mathrm{y}_{\mathrm{f}}=\mathrm{a}_{\mathrm{f}} \mathrm{l}_{\mathrm{f}}^{\theta} \mathrm{k}_{\mathrm{f}}^{(1-\theta)}
$$

where $\mathrm{y}_{\mathrm{f}}=$ output, $\mathrm{l}_{\mathrm{f}}=$ labor, and $\mathrm{k}_{\mathrm{f}}=$ capital. Then, under our stated assumptions, the industrylevel production function is

$$
\mathrm{Y}=\Sigma\left(\mathrm{z}_{\mathrm{f}} \mathrm{a}_{\mathrm{f}}\right) \mathrm{L}^{\theta} \mathrm{K}^{(1-\theta)}=\mathrm{AL}^{\theta} \mathrm{K}^{(1-\theta)}
$$

where $\mathrm{Y}=\Sigma \mathrm{y}_{\mathrm{f}}, \mathrm{L}=\Sigma \mathrm{l}_{\mathrm{f}}, \mathrm{K}=\Sigma \mathrm{k}_{\mathrm{f}}$, and $\mathrm{z}_{\mathrm{f}}=\mathrm{k}_{\mathrm{f}} / \mathrm{K}=\mathrm{l}_{\mathrm{f}} / \mathrm{L}$.

The industry-level technology parameter, $\Sigma\left(\mathrm{z}_{\mathrm{f}} \mathrm{a}_{\mathrm{f}}\right)=\mathrm{A}$, reflects both the firm-level technologies $\mathrm{a}_{\mathrm{i}}$ and the allocation of factor inputs within the industry. So, for example, a technological change at the industry level $\Delta \mathrm{A}$ comprises not only technical change by firms $\Delta \mathrm{a}_{\mathrm{f}}$, but also any changes in shares of the respective firms'employment of industry inputs that are induced through the posited oligopolistic equilibrium. The basic logic here is that of Zarembka (1968).

A further serious issue in estimates of industry level production functions is identification. Specifically, when shifts in the production function are anticipated by firms, then they can be 
expected to adjust their employment of labor and capital. In this case the employment of labor and capital is correlated with the statistical error term in econometric estimates of the production function, and the estimated OLS coefficients are thus biased and inconsistent, as fully elucidated by Griliches and Mairesse (1998). Valid instruments for labor and capital might be found, particularly if one of these (capital) responds to productivity shocks with a lag. Then lagged values of capital become suitable instruments for contemporaneous employment of labor. This is the basic approach of the dynamic panel data literature (Olley and Pakes (1996), Blundell and Bond (2000), and Ackerberg, Caves, and Fraser (2004)). But that literature focuses on micropanel data, that is with many cross-sections but relatively few time periods. Typically the unit of analysis in such panel data is the firm, not, as here, the industry. A different way forward is needed. Again the maintained assumption of constant returns to scale is helpful.

First note that for the Cobb-Douglas production function as in (2) above, we have that for each industry,

$$
\mathrm{Y}=\mathrm{AL}(\mathrm{K} / \mathrm{L})^{(1-\theta)}
$$

and the identification problem is simply that of estimating the coefficient on $\mathrm{K} / \mathrm{L}$. That is, if businesses adjust their employment of both capital and labor equally in response to perceived productivity shocks, then endogeneity bias is absent. Notice that the maintained assumption of constant returns to scale is crucial to this. But is it plausible that employment of capital and labor would be equally flexible? Labor is typically regarded as a variable input and capital as fixed in the short run. However in Japanese manufacturing industries, the well-documented practice of lifetime employment should weaken this presumption. It is reasonable to suppose that Japanese manufacturers'employment of both labor and capital respond sluggishly to anticipated productivity shocks, mitigating the problem of endogeneity bias.

\section{Econometric Model}

In the empirical literature on production functions, econometric specification is very much dependent upon the nature of the available data. Ours is a panel data set of calender year observations 1961-1990, for 74 manufacturing industries, including observations of average annual wholesale price index, Herfindahl index of production, and various establishment-based 
items including value added, value of shipments, employment, wages and book value of fixed tangible assets. All data were not available for all years so this represents an unbalanced panel data set. For a description of the data sources see Appendix 1. One important aspect of these data has already been noted: It is aggregated to the 4-digit s.i.c. level. Another thing to note is that we observe physical units of labor, number of employees, but only observe nominal units of capital, namely, book value of tangible assets. Accordingly, I will adopt a specification in which the multiplicative factor for converting units of capital from nominal book value to economically meaningful units of measurement is an estimable parameter.

We estimate an equation on the pooled annual time-series, cross-section of 74 industries at the 4-digit s.i.c. level, 1961-1990. The regression equation is the following:

$$
\ln \mathrm{Q}_{\mathrm{it}}=\mathrm{A}_{\mathrm{i}}+\left(1-\theta_{\mathrm{i}}\right) \mathrm{A}_{\mathrm{t}}+\theta_{\mathrm{i}} \ln \mathrm{L}_{\mathrm{it}}+\left(1-\theta_{\mathrm{i}}\right) \ln \mathrm{K}_{\mathrm{it}}+\mathrm{v}_{\mathrm{it}}, \quad \mathrm{i}=1 \ldots, \mathrm{n} ; \mathrm{t}=1, \ldots, \mathrm{T} .
$$

or equivalently,

$$
\ln \mathrm{Q}_{\mathrm{it}}=\mathrm{A}_{\mathrm{i}}+\theta_{\mathrm{i}} \ln \mathrm{L}_{\mathrm{it}}+\left(1-\theta_{\mathrm{i}}\right) \ln \mathrm{e}^{\mathrm{At}} \mathrm{K}_{\mathrm{it}}+\mathrm{v}_{\mathrm{it}}, \quad \mathrm{i}=1 \ldots, \mathrm{n} ; \mathrm{t}=1, \ldots, \mathrm{T} .
$$

Here $Q_{i t}$ represents value of shipments by industry $i$ in year $t$ divided by average monthly wholesale price index for the corresponding product during the same year. The labor input is $\mathrm{L}_{\mathrm{it}}$, defined as the number of workers employed in the industry $\mathrm{i}$ in year $\mathrm{t}$. And $\mathrm{K}_{\mathrm{it}}$ is the book value of the fixed tangible assets of the industry $i$ at the beginning of year $t$.

The error term $\mathrm{v}_{\mathrm{it}}$ is likely to exhibit autocorrelation. Technological advance manifests itself as positive autocorrelation, and in principle at least, perfect autocorrelation. But few things in life are perfect, and in any case there are additional forces at work. For instance, if our dependent variable shipments varies with the business cycle it would induce some negative autocorrelation, abnormally high shipments in a boom year followed by abnormally low shipments the following year. We estimate these equations with adjustment for first-order autocorrelation, that is in which for each industry $i$, the error term in equation (5) is presumed to follow the stochastic process

$$
\mathrm{v}_{\mathrm{it}}=\rho_{\mathrm{i}} \mathrm{v}_{\mathrm{i}, \mathrm{t}-\mathrm{1}}+\mathrm{u}_{\mathrm{it}}, \quad \text { and } \mathrm{u}_{\mathrm{it}} \sim\left(0, \sigma_{\mathrm{i}}^{2}\right)
$$


We estimate the parameters $A_{i}, A_{t}, \theta_{i}$ and $\rho_{i}$. This was accomplished by an iterative application of two-way fixed effects and AR1 regression estimates using the SAS software. See Appendix 2 for details. Now the parameters $A_{t}, t=1, \ldots, T$, comprise both the deflator of the nominal book-value measure of capital $\mathrm{K}_{\mathrm{it}}$ and also include Hicks-neutral technological change that is common to all of the industries. That is, $\mathrm{e}^{\mathrm{At}} \mathrm{K}_{\mathrm{it}}$ represents the capital stock of industry $\mathrm{i}$ in year $\mathrm{t}$ measured in efficiency units calibrated to the pan-industry state of technology. Klette (1999) uses the same technique of statistically estimating the deflator of book-value of capital stock rather than constructing it from price indices and questionable assumptions about tax rates and depreciation.

Our estimates of the implicit capital deflator $\mathrm{e}^{\mathrm{At} *}$ seem to embody substantial technological improvement. If there were merely inflation of nominal book value of capital stock, and no panindustry technological advance, our adjustment factor $\mathrm{e}^{\mathrm{At} *}$, calibrated so that $1990=1$, should decline as prices rise. But in fact it rises. By how much would inflation alone cause $\mathrm{e}^{\mathrm{At}}$ to fall? The deflator for non-residential investment used in Japan's System of National Accounts (SNA) affords one measure of inflation. This is represented in Table 1, along with our estimates of $\mathrm{e}^{\mathrm{At} *}$. The fact that $\mathrm{e}^{\mathrm{At} *}$ tends to rise even as prices rise indicates that technological advance embodied in our implicitly constructed "efficiency units" measure of capital outstrips inflation. An estimate of the efficiency unit per actual physical unit of capital in each year can be constructed by multiplying $\mathrm{e}^{\mathrm{At} *}$ by the SNA investment deflator. The sense of this is that $\mathrm{e}^{\mathrm{At} *}=$ capital in efficiency units/ capital in nominal units; SNA investment deflator $=$ capital in nominal units/ capital in physical units; and so $\mathrm{e}^{\mathrm{At} *} \times \mathrm{SNA}$ investment deflator $=$ capital in efficiency units/ capital in physical units. The last column of Table 1, which is also plotted in Figure 1, depicts this measure of efficiency unit per actual physical unit of capital in each year.

Because our measure of labor is the number of workers employed each year, which is a physical unit of measurement, virtually all (pan-industry) technological advance is reflected in our "efficiency units" measure of capital. Not only improvements in machines and tools themselves, but also improvements in the quality of labor, including advances in education or enhancement of skills, will show up in our estimates as improvements in the efficiency of capital. Thus the increase in efficiency unit per actual unit of capital embodies the entirety of panindustry technological advance. This measure grows from 0.305 in 1961 to 1.0 in 1990, an average annual exponential growth rate of 3.96 percent. Given our estimated average elasticity of output with respect to capital of 0.43 , this implies an overall average rate of Hicks neutral 
technological advance of about 1.7 percent $(=0.43 \times 3.96$ percent $)$. This is a very plausible estimate of technological advance in our set of industries, most of which are old-line, mature manufacturing industries. Since 1935, Japan's average rate of increase in real GDP per capita, one rough measure of technological advance, is around 3 percent. Flath (2005, at p. 89).

Estimates of industry-specific parameters and related statistics are represented in Table 2. These estimates include, for each industry, an estimate of the elasticity of output with respect to labor $\theta_{\mathrm{i}}{ }^{*}$. The residuals $\mathrm{v}_{\mathrm{it}}{ }^{*}$ from these regressions represent estimates of the industry-specific technical change, that is deviations from the pan-industry technical change embodied in $\mathrm{A}_{\mathrm{t}}{ }^{*}$, in effect Solow residuals. These residuals are the difference between actual observation of dependent variable and that predicted based on the structural equation. Later in the paper I will further describe the residuals from these regressions.

The estimated coefficients on $\ln \mathrm{L}_{\mathrm{it}}$ vary from industry to industry in a way that comports with common sense notions as to which industries are likely to employ more capital intensive methods. So for example the most capital intensive industries are estimated to be:

Synthetic Fibers $\left(1-\theta_{\mathrm{i}}^{*}=0.69\right)$

Medicines $\left(1-\theta_{\mathrm{i}}^{*}=0.67\right)$

Glass Bulbs For Use In Cathode Ray Tubes $\left(1-\theta_{i}^{*}=0.63\right)$

Wrist Watches $\left(1-\theta_{\mathrm{i}}^{*}=0.63\right)$

Plastic-working Machines $\left(1-\theta_{\mathrm{i}}^{*}=0.58\right)$

Pumps $\left(1-\theta_{i}^{*}=0.58\right)$

...and the least capital intensive are

Briquettes $\left(1-\theta_{i}^{*}=0.05\right)$

Weaving Machines $\left(1-\theta_{\mathrm{i}}^{*}=0.22\right)$

Jute Yarn $\left(1-\theta_{i}^{*}=0.23\right)$

Worsted Yarn $\left(1-\theta_{i}^{*}=0.26\right)$

Miso $\left(1-\theta_{i}^{*}=0.26\right)$

Our specification presumes constant returns to scale, both at the unobserved level of individual firms and at the level of the industry. We make no presumption regarding the state of competition in each industry. But we are able to construct estimates of price-cost margins for each industry in each year. The basic logic here follows that of Hall (1988). For each industry $\mathrm{i}$ we directly observe nominal value-added $\mathrm{Y}_{0 \mathrm{it}}$ and wage payments $\mathrm{W}_{0 \mathrm{it}} \mathrm{L}_{\mathrm{it}}$. (Let the subscript " 0 " in " $\mathrm{Y}_{0 \mathrm{it}}$ " and $\mathrm{W}_{0 \mathrm{it}}$ " remind us that these are expressed in nominal units). We presume that 
labor's share of total cost in each industry equals our estimate of the output elasticity with respect to labor. Thus nominal total $\operatorname{cost} \mathrm{C}_{0 \mathrm{i}}$, including both labor cost and capital cost, is estimated as the wage bill divided by our estimate of the output elasticity with respect to labor

$$
\mathrm{C}_{0 \mathrm{it}}^{*}=\left(\mathrm{W}_{0 \mathrm{it}} \mathrm{L}_{\mathrm{it}}\right) / \theta_{\mathrm{i}}^{*}
$$

And our estimate of the nominal profit $\pi_{0 \mathrm{it}}$ in each industry $\mathrm{i}$ in each year $\mathrm{t}$ is value-added minus cost:

$$
\pi_{0 \mathrm{it}}=\mathrm{Y}_{0 \mathrm{it}}-\mathrm{C}_{0 \mathrm{it}}{ }^{*}
$$

From these data we further construct industry-level price-cost margins $\mathrm{m}_{\mathrm{it}}$ as the ratio of profit to value of shipments:

$$
\mathrm{m}_{\mathrm{it}}=\pi_{0 \mathrm{it}} / \mathrm{Q}_{0 \mathrm{it}} .
$$

These price-cost margins average 11.5 percent over all industries and years as shown in the last column of Table 4. A companion paper to this one (Flath , 2009), explores the temporal relation between these price-cost margins and the annual time series of Herfindahl index of concentration in each industry. Under the simple homogenous product Cournot model, industry price-cost margin is proportionate to Herfindahl, and the constant of proportionality is the reciprocal of elasticity of demand facing the industry. If, on the other hand, each industry comprises a collection of price-setting and product differentiated firms -i.e is in a Bertrand pricing equilibrium- then the industry price-cost margin is a weighted average of the reciprocal demand elasticities facing each firm. A non-nested test (Vuong test based on Vuong (1989)) comparing these two specifications for each of the 74 industries shows that product differentiated Bertrand is a better characterization than homogeneous product Cournot for most of the industries.

Our main focus here is on determinates of industrial concentration and of innovation, and upon the relation between the two. We first examine the extent to which our estimates of CobbDouglas labor coefficients and industry price-cost margins adequately explain the observed pattern of concentration. Then we consider whether there is any association between industrial 
concentration and rate of innovation. And finally, we ask, is there an inverted-U mapping from price-cost margin to the rate of innovation as argued by Aghion et al. (2005).

\section{Empirical Results}

\subsection{Determinates of industrial concentration}

The data we have constructed enable a simple empirical analysis of inter-industry variation in concentration. It is quite reasonable to suppose that industries that employ more capital intensive methods of production should be more concentrated ceteris paribus. This is because capital inputs are inherently lumpy and thus likely to be employed only by large firms. But an industry that employs capital intensely can nevertheless accommodate many firms if the scale of demand facing the industry is large. Further, a larger number of firms can profitably coexist in industries that face less elastic demand, ceteris paribus, as argued by Sutton (1998). On the other hand, inelastic demand may well be associated with customer loyalty to incumbent firms, which would tend to discourage entry and thus promote concentration. I break no new ground here and simply restate textbook propositions of industrial organization, common to many specific oligopoly theories, but the empirical content of these propositions remains an open question. To the extent incumbent firms have superior technology to that of potential entrants, there is no necessary relation between any of these variables -capital intensity, scale of demand, elasticity of demand-and industrial concentration. A modest step toward addressing this issue is possible here by estimating the following simple regression:

$$
\mathrm{H}_{\mathrm{it}}=\beta_{0}+\beta_{1} \mathrm{~m}_{\mathrm{it}}+\beta_{2} \theta_{\mathrm{i}}^{*}+\beta_{3} \ln \mathrm{L}_{\mathrm{it}}+\varepsilon_{\mathrm{it}},
$$

where $H_{i t}$ is the Herfindahl index for industry $i$, in year $t ; m_{i t}$ is the price-cost margin; $\theta_{i}{ }^{*}$ is our estimate of the elasticity of output with respect to labor of industry $i$;and $\ln L_{i t}$ is the natural $\log$ of employment of labor by industry i. In other words, the Herfindahl index is a linear function of price-cost margin, capital intensity, and industry scale. We estimate the equation using a pooled two-way random effects procedure. That is we presume that the error term has a crosssection component, time-series component, and pooled component :

$$
\varepsilon_{\mathrm{it}}=\varepsilon_{\mathrm{i}}+\varepsilon_{\mathrm{t}}+\mathrm{v}_{\mathrm{it}},
$$


and weight observations according to sample estimates of their corresponding conditional variances. This is an unbalanced panel data set. Observations are weighted according to the Wansbeek and Kapteyn (1989) modification of the Fuller and Battese (1974) procedure.

Table 3 has the random-effects estimates of equation (12). Effectively, the time-series component of variance is estimated to be zero. The variables explain only about seven percent of the variation in Herfindahl index. Price-cost margin is statistically significant and has a positive sign, which comports with the idea that high price-cost margin is associated with customer loyalty to incumbent firms, which impedes entry and promotes concentration. The capital coefficient and industry scale are highly significant and have the expected signs. Industries that use capital intensely tend to be more concentrated. Industries that employ more workers tend to be less concentrated.

4.2 Technical advance, concentration and price-cost margins

We now turn attention to the interrelation between technical change and concentration. There are many theories with conflicting predictions as to whether industrial concentration promotes innovation, or retards it, or indeed whether it has any significant effect at all. For a recent discussion of this literature consult Okada (2005).

Our measures of technical advance are residuals $\mathrm{v}_{\mathrm{it}}$ * from Cobb-Douglas regressions of real value of shipments on measures of labor and capital. We now consider how is this measure of technical advance related to industrial concentration and to price-cost margins. This is primarily a question about the variation in technical change across industry, so we need to construct industry-level measures of technical advance. To do this, we calculate trend regressions:

$$
\mathrm{v}_{\mathrm{it}}^{*}=\gamma_{0 \mathrm{i}}+\gamma_{1 \mathrm{i}} \mathrm{t}+\varepsilon_{\mathrm{it}}, \quad \mathrm{i}=1, \ldots, \mathrm{n} \text {. }
$$

The slope coefficients $\gamma \mathrm{j}_{1}$ * from these regressions represent relative measures of average rate of technical advance for each industry. That is, $\gamma_{1 i}{ }^{*}$ represents the average annual exponential growth rate in the Solow residual constructed from AR1 estimates of Cobb-Douglas production functions. These statistics are reported in Table 4, along with industry-by-industry averages for Herfindahl index and for the price-cost-margins $\mathrm{m}_{\mathrm{it}}$ we constructed from earlier estimates. 
Actually these represent deviations from the pan-industry rate of technical advance embodied in our capital stock deflator.

We regress this measure $\gamma_{1 i}{ }^{*}$ of average rate of technical advance on the mean and squared mean of the Herfindahl index for each industry i:

$$
\gamma_{\mathrm{i}}^{*}=\beta_{0}+\beta_{1} \overline{\mathrm{H}}_{\mathrm{i}}+\beta_{2} \overline{\mathrm{H}}_{\mathrm{i}}^{2}+\varepsilon_{\mathrm{i}}
$$

Further we regress the same measures of technical change on the mean and squared mean of the price-cost margin for each industry:

$$
\gamma_{1 i}^{*}=\beta_{0}+\beta_{1} \bar{m}_{\mathrm{i}}+\beta_{2} \overline{\mathrm{m}}_{\mathrm{i}}^{2}+\varepsilon_{\mathrm{i}}
$$

The estimates of equations (14) and (15) are in Table 5. The regression curve and plots of observations for estimates of equation (14) are in the Figure 1. These results amount to a nearly flat, but U-shaped, pattern in which industries with either high concentration $(\mathrm{H}>0.4)$ or low concentration $(\mathrm{H}<0.2)$ exhibit substantially more innovation (around 0.5 percent per year faster rate of change in Hicks neutral innovation) than those with moderate levels of concentration. The relation between price-cost margin and rate of innovation is similar but much weaker. In short, we do not find in these data the inverted U-shaped mapping from industry price-cost margins to innovation touted by Aghion, et al (2005).

\section{Conclusion}

This paper has explored a panel data set matching establishment-based production statistics from Japan's Census of Manufacturers with wholesale price indices from the Bank of Japan, and Herfindahl indices from the Japan Fair Trade Commission. The data include annual observations over the period 1961-1990 for 74 industries at the 4-digit s.i.c. level. We estimated CobbDouglas production functions and Solow residuals for each industry and then used these estimates to further analyse the determinates of industrial concentration and innovation. 
We found that the industries in our sample tended to be more concentrated the more intensely they employed capital and the smaller their overall scale. There is also some indication that industries that face less elastic demand tend to be more concentrated.

The industries that exhibited the highest rates of technical advance included both highly concentrated ones (Glass Bulbs for CRTs, Wrist Watches, Jute Yarn) and more atomistic ones (Cotton Yarn, Medicines, Valve Cocks). We could discern no monotonic relation between concentration and innovation nor between price-cost margins and innovation. But there does appear to be a U-shaped mapping from concentration to innovation in these data. 
I have constructed a panel data set by merging 1961-1990 calender year observations from three different sources for the intersecting subset of 4-digit s.i.c. industries, of which there were 74.

From Japan's Census of Manufacturers - Report by Industries, listed in the references under the author MITI, we draw value-added, value of shipments, employment, wages, and book value of fixed tangible assets. The book value of tangible assets is observed for establishments employing 10 or more. All other items are for establishments employing 4 or more. The book value of tangible assets is observed at the beginning of the calender year. These data and continuation of like data through 2002, are available for downloading from the website of the Ministry of Economy, Trade and Industry (METI) here:

http://www.meti.go.jp/statistics/kougyou/arc/index.html

From two published sources and a website we compile observations of Herfindahl index of industrial concentration of production. The two published sources are JFTC (1975) and Senou (1983). These data are collected by the Japan Fair Trade Commission in fulfillment of its charge under the antimonopoly law. The two sources comprise overlapping time-series, respectively: (1960-1972) and (1971-1980). The series are continued (1975-2002) in data posted on the website of the Japan Fair Trade Commission from which I was able to extend my data through 1990:

http://www.jftc.go.jp/ruiseki/ruisekidate.htm,

The FTC observations on Herfindahl indices, both from the published sources and the web site, represent the summation of squared shares of industry production for nearly 500 industries. These data are, in principle, shares of physical units produced, not shares of revenues. But apparently for many of the industries a production index is used in lieu of physical units.

Finally we collect the monthly observations of wholesale price index series for each commodity, from the Bank of Japan for 1962-1990. Monthly data from 1985 on are available in electronic format from the website of the BOJ here:

http://www.boj.or.jp/en/type/stat/dlong/index.htm

Earlier data were drawn from the BOJ serial Price Indices Annual. From these sources I converted linked series to common 1980 base year units and calculated calender year averages for each. 
The three sets of data correspond to imperfectly matched industries. I was able to identify an overlapping subset of 74 industries with observations from all three sources (corresponding to the 4-digit s.i.c. level in the Census of Manufacturers). This is a relatively small subset of any of the three sources. For example there are about 450 industries for which the JFTC reports Herfindahl indices and more than a thousand commodities for which the BOJ tracks wholesale price indices. And Japan's Census of Manufacturers identifies around 700 of 4-digit s.i.c. industries. Other scholars have merged these same three sources in approximately the same way as I have, and so I cross checked my list of matched industries with theirs. The three are Nishikawa (1973), Shinjou (1977), and Kusuda and Ike (1979). 
Appendix 2. Iterative procedure for estimating implicit capital deflator.

We here detail the procedure used to estimate the implicit capital deflator $\mathbf{A}_{\mathbf{t}}$ of equation (5) from the text:

(A1) $\quad \ln \mathrm{Q}_{\mathrm{it}}=\mathrm{A}_{\mathrm{i}}+\theta_{\mathrm{i}} \ln \mathrm{L}_{\mathrm{it}}+\left(1-\theta_{\mathrm{i}}\right) \ln \mathrm{e}^{\mathrm{At}} \mathrm{K}_{\mathrm{it}}+\mathrm{v}_{\mathrm{it}}$, $\mathrm{i}=1 \ldots, \mathrm{n} ; \mathrm{t}=1, \ldots, \mathrm{T}$.

This is accomplished by iterative application of SAS procedures "proc tscs" and "proc autoreg". We first estimate the parameters $\left(\mathrm{A}_{\mathrm{i}}^{(1)}, \mathrm{A}_{\mathrm{t}}^{(1)}, \theta_{\mathrm{L}}^{(1)}, \theta_{\mathrm{K}}^{(1)}\right)$ in a two-way fixed effects regression equation on the pooled sample:

(A2) $\quad \ln \mathrm{Q}_{\mathrm{it}}=\mathrm{A}_{\mathrm{i}}^{(1)}+\mathrm{B}_{\mathrm{t}}^{(1)}+\theta_{\mathrm{L}}^{(1)} \ln \mathrm{L}_{\mathrm{it}}+\theta_{\mathrm{K}}^{(1)} \ln \mathrm{K}_{\mathrm{it}}+\xi_{\mathrm{it}}$, $\mathrm{i}=1 \ldots, \mathrm{n} ; \mathrm{t}=1, \ldots, \mathrm{T}$.

or equivalently,

(A3) $\quad \ln \mathrm{Q}_{\mathrm{it}}=\mathrm{A}_{\mathrm{i}}^{(1)}+\theta_{\mathrm{L}}^{(1)} \ln \mathrm{L}_{\mathrm{it}}+\theta_{\mathrm{K}}^{(1)} \ln \left[\mathrm{K}_{\mathrm{it}} \exp \left(\mathrm{B}_{\mathrm{t}}^{(1)} / \theta_{\mathrm{K}}^{(1)}\right)\right]+\xi_{\mathrm{it}}, \quad \mathrm{i}=1 \ldots, \mathrm{n} ; \mathrm{t}=1, \ldots, \mathrm{T}$.

We next estimate, for each industry $i$, parameters $\left(a_{i}^{(1)}, \theta_{i}^{(1)}, \rho_{i}^{(1)}\right)$ in AR1 regression equations of the following sort,

$$
\begin{aligned}
& \ln \mathrm{Q}_{\mathrm{it}}=\mathrm{a}_{\mathrm{i}}^{(1)}+\theta_{\mathrm{i}}^{(1)} \ln \mathrm{L}_{\mathrm{it}}+\left(1-\theta_{\mathrm{i}}^{(1)}\right) \ln \left[\mathrm{K}_{\mathrm{it}} \exp \left(\mathrm{B}_{\mathrm{t}}^{(1)^{*} / \theta_{\mathrm{K}}}{ }^{(1)^{*}}\right)\right]+\mathrm{v}_{\mathrm{it}}, \\
& \mathrm{v}_{\mathrm{it}}=\rho_{\mathrm{i}}^{(1)} \mathrm{v}_{\mathrm{i}, \mathrm{t}-1}+\mathrm{u}_{\mathrm{it}}, \quad \text { and } \mathrm{u}_{\mathrm{it}} \sim\left(0, \sigma_{\mathrm{i}}^{2}\right) .
\end{aligned}
$$

where asterisks * denote estimates from a previous regression.

We continue the iteration, replacing $\ln \mathrm{L}_{\mathrm{it}}$ and $\ln \mathrm{K}_{\mathrm{it}}$ in equations (A2) and (A3) with

(A5) $\quad \theta_{\mathrm{i}}^{(1)^{*}} \ln \mathrm{L}_{\mathrm{it}}$

and

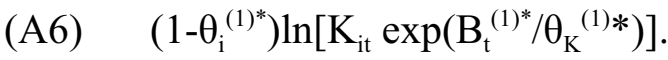


That is, we again estimate parameters $\left(\mathrm{A}_{\mathrm{i}}{ }^{(2)}, \mathrm{B}_{\mathrm{t}}{ }^{(2)}, \lambda_{\mathrm{L}}{ }^{(1)}, \lambda_{\mathrm{K}}{ }^{(1)}\right)$ of a two-way fixed effects regression for the pooled sample:

(A7) $\quad \ln \mathrm{Q}_{\mathrm{it}}=\mathrm{A}_{\mathrm{i}}^{(2)}+\mathrm{B}_{\mathrm{t}}^{(2)}+\lambda_{\mathrm{L}}^{(1)} \theta_{\mathrm{i}}^{(1) *} \ln \mathrm{L}_{\mathrm{it}}+\lambda_{\mathrm{K}}^{(1)}\left(1-\theta_{\mathrm{i}}^{(1) *}\right) \ln \left[\mathrm{K}_{\mathrm{it}} \exp \left(\mathrm{B}_{\mathrm{t}}^{(1)^{*}} / \theta_{\mathrm{K}}^{(1)^{*}}\right)\right]+\xi_{\mathrm{it}}$, $\mathrm{i}=1 . ., \mathrm{n}$; $\mathrm{t}=1, \ldots, \mathrm{T}$.

or equivalently,

(A8) $\ln \mathrm{Q}_{\mathrm{it}}=\mathrm{A}_{\mathrm{i}}^{(2)}+\lambda_{\mathrm{L}}^{(1)} \theta_{\mathrm{i}}^{(1)^{*}} \ln \mathrm{L}_{\mathrm{it}}+\lambda_{\mathrm{K}}^{(1)}\left(1-\theta_{\mathrm{i}}^{(1) *}\right) \ln \left[\mathrm{K}_{\mathrm{it}} \exp \left(\mathrm{B}_{\mathrm{t}}^{(1)^{*}} / \theta_{\mathrm{K}}^{(1)^{*}}\right) \exp \left(\mathrm{B}_{\mathrm{t}}^{(2)} / \lambda_{\mathrm{K}}^{(1)}\right)\right]+\xi_{\mathrm{it}}$, $\mathrm{i}=1 . ., \mathrm{n}$; $\mathrm{t}=1, \ldots, \mathrm{T}$.

And again we estimate, for each industry $i$, parameters $\left(a_{i}^{(2)}, \theta_{i}^{(2)}, \rho_{i}^{(2)}\right)$ of AR1 regression equations of the following sort:

$$
\begin{aligned}
& \ln \mathrm{Q}_{\mathrm{it}}=\mathrm{a}_{\mathrm{i}}^{(2)}+\theta_{\mathrm{i}}^{(2)} \ln \mathrm{L}_{\mathrm{it}}+\left(1-\theta_{\mathrm{i}}^{(2)}\right) \ln \left[\mathrm{K}_{\mathrm{it}} \exp \left(\mathrm{B}_{\mathrm{t}}^{(1)^{*} / \theta_{\mathrm{K}}}{ }^{(1)^{*}}\right) \exp \left(\mathrm{B}_{\mathrm{t}}^{(2)^{*}} / \lambda_{\mathrm{K}}^{\left.(1)^{*}\right)}\right]+\mathrm{v}_{\mathrm{it}}\right. \text {, } \\
& \mathrm{v}_{\mathrm{it}}=\rho_{\mathrm{i}}^{(2)} \mathrm{v}_{\mathrm{i}, \mathrm{t}-1}+\mathrm{u}_{\mathrm{it}}, \quad \text { and } \mathrm{u}_{\mathrm{it}} \sim\left(0, \sigma_{\mathrm{i}}^{2}\right) \text {. }
\end{aligned}
$$

We continue the iteration, replacing $\theta_{\mathrm{i}}^{(1)^{*}} \ln \mathrm{L}_{\mathrm{it}}$ and $\left(1-\theta_{\mathrm{i}}^{(1)^{*}}\right) \ln \left[\mathrm{K}_{\mathrm{it}} \exp \left(\mathrm{B}_{\mathrm{t}}^{(1)^{*}} / \theta_{\mathrm{K}}^{(1) *}\right)\right]$ in equation (A8) with

$$
\theta_{i}^{(2) *} \ln L_{i t}
$$

and

$$
\left(1-\theta_{\mathrm{i}}^{(2)^{*}}\right) \ln \left[\mathrm{K}_{\mathrm{it}} \exp \left(\mathrm{B}_{\mathrm{t}}^{(1)^{*} / \theta_{\mathrm{K}}}{ }^{(1) *}\right) \exp \left(\mathrm{B}_{\mathrm{t}}^{(2)^{*}} / \lambda_{\mathrm{K}}{ }^{(1)^{*}}\right)\right]
$$

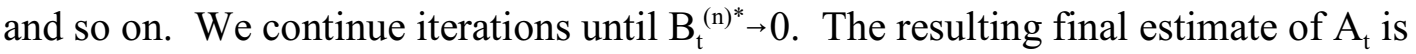

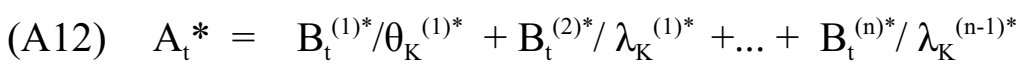

Satisfactory convergence required three iterations. 


\section{References}

Ackerberg, Daniel; Caves, Kevin and Fraser, Garth (2004). "Structural Identification of Production Functions," mimeo, UCLA.

Aghion, Philippe ; Bloom, Nick; Blundell, Richard ; Griffith, Rachel; and Howitt, Peter (2005). “Competition and Innovation: An Inverted-U Relationship", The Quarterly Journal of Economics, Vol. 120, Issue 2 (May), pp. 701-728.

Bank of Japan (Serial). Price Indexes Annual. Nihon ginkou toukeikyoku, Serial [1970-2002].

Blundell, Richard and Bond, Steve (2000). "GMM Estimation with Persistent Panel Data: An Application to Production Functions," Econometric Reviews, Vol. 19, pp. 321-340.

Flath, David. (2009). “Are There Any Cournot Industries?”, unpublished manuscript.

Flath, David. (2005). The Japanese Economy, Oxford: Oxford University Press, second edition.

Fuller, Wayne A. and Battese, G. E. (1974). "Estimation of Linear Models with Crossed-Error Structure," Journal of Econometrics, vol. 2, pp. 67-78.

Griliches, Zvi. and Jacques Mairesse. (1998). "Production Functions: The Search for Identification." in: Econometrics and Economic Theory in the Twentieth Century: The

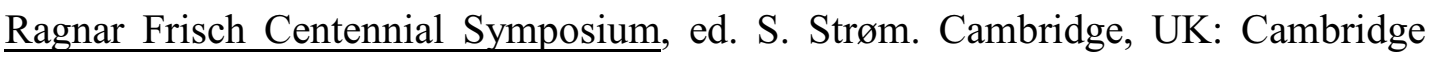
University Press.

Hall, Robert E. (1988). "The Relation between Price and Marginal Cost in U.S. Industry," Journal of Political Economy, vol. 96, no. 5 (Oct.), pp. 921-947.

JFTC [kousei torihiki iinki jimu kyoku hen (Japan Fair Trade Commission, executive office, ed.) ] (1974). Dokusen kin konkai shiryou shuu IV (Antitrust meeting data set), oukurasho insatsu kyoku seizou. 
JFTC [kousei torihiki iinki jimu kyoku hen (Japan fair trade commission, executive office, ed.) ] (1975). Shuuyou sangyou ni okeru ruiseki seisan shucchuudo to haafindaaru shisuu no suii (shouwa 35 nen - 47 nen) (Cumulative concentration and Herfindahl index measures of industrial concentration in major industries, 1960-1972), zaidan houjin kousei torihiki kyoukai.

Klette, Tor Jakob (1999). "Market Power, Scale Economies and Productivity: Estimates from a Panel of Establishment Data", The Journal of Industrial Economics, vol. 47, no. 4 (December), pp. 451-476.

Kusuda, Tadashi and Ike, Suguru (1979). Seizougyou no kakaku hendo youin bunseki (Analysis of the causes of price variation in manufacturing industries), keizai bunseki, vol. 76, pp. 91-167.

Ministry of International Trade and Industry (Serial). Kougyou toukei hyou (Census of Manufacturers - Report by Industries).

Nakajima, Takanobu,; Nakamura, Masao; and Yoshioka, Kanji (1998). “An Index Number Method for Estimating Scale Economies and Technical Progress Using Time-Series or Cross-Section Data Sources of Total factor Productivity Growth for Japanese Manufacturing, 1964-1988", The Japanese Economic Review, vol. 49, no. 3 (September), pp. 310-334.

Nishikawa T. (1973). Kanri kakaku infureeshon to kasen (Administered price inflation and oligopoly), kikan gendai keizai, vol. 9 (summer), pp. 128-141.

Nishimura, Kiyohiko; Ohkusa, Yasushi; and Ariga, Kenn. (1999). "Estimating the Mark-up Over Marginal Cost: A Panel Analysis of Japanese Firms 1971-1994", International Journal of Industrial Organization, Volume 17, Issue 8 (November), Pages 1077-1111. 
Okada, Yosuke (2005). "Competition and Productivity in Japanese Manufacturing Industries", Journal of the Japanese and International Economies, Vol. 19, issue 4 (December), pp. 586-616.

Olley, G. Steven and Pakes, Ariel (1996). "The Dynamics of Productivity in the Telecommunications Equipment Industry," Econometrica, vol. 64, no. 6, pp. 12631298.

Senou, Akira (1983). Gendai nihon no sangyou shucchuu (Industrial concentration in contemporary Japan), nihon keizai shinbunsha, 1983.

Shinjo, Koji (1977). (An analyis of the inter-industry wage sturcture variation: The Japanese manufacturing 1957-1972) kokumin keizai zasshi, vol. 135, no.4 (Arpil), pp. 54-76.

Sutton, John (1998). Technology and Market Structure, Cambridge, MA: The MIT Press.

Vuong, Quang H. (1989) "Likelihood Ratio Tests for Model Selection and Non-Nested Hypotheses", Econometrica, vol. 57, no. 2 (March), pp. 307-333.

Wansbeek, T., and Kapteyn, Arie (1989). "Estimation of the Error-Components Model with Incomplete Panels,” Journal of Econometrics, vol. 41, no. 4, pp. 733-750.

Zarembka, Paul (1968). "A Note on Consistent Aggregation of Production Functions," Econometrica, vol. 36, No. 2 (April), pp. 419-420. 
Table 1. Implicit deflator of capital stock and SNA deflator.

\begin{tabular}{|c|c|c|c|}
\hline & $\mathrm{e}^{\mathrm{At} t_{*}}$ & SNA & Implied \\
\hline & & Deflator & $\begin{array}{c}\text { Efficiency Units } \\
\text { of Capital per }\end{array}$ \\
\hline 1961 & 0.667 & 0.458 & $\begin{array}{c}\text { Actual Unit } \\
0.305\end{array}$ \\
\hline 1962 & 0.225 & 0.464 & 0.104 \\
\hline 1963 & 0.246 & 0.464 & 0.114 \\
\hline 1964 & 0.3 & 0.468 & 0.140 \\
\hline 1965 & 0.301 & 0.473 & 0.142 \\
\hline 1966 & 0.333 & 0.484 & 0.161 \\
\hline 1967 & 0.443 & 0.495 & 0.219 \\
\hline 1968 & 0.504 & 0.501 & 0.252 \\
\hline 1969 & 0.56 & 0.506 & 0.283 \\
\hline 1970 & 0.625 & 0.519 & 0.324 \\
\hline 1971 & 0.634 & 0.531 & 0.336 \\
\hline 1972 & 0.657 & 0.548 & 0.360 \\
\hline 1973 & 0.736 & 0.616 & 0.453 \\
\hline 1974 & 0.595 & 0.762 & 0.453 \\
\hline 1975 & 0.535 & 0.798 & 0.427 \\
\hline 1976 & 0.62 & 0.830 & 0.514 \\
\hline 1977 & 0.739 & 0.868 & 0.641 \\
\hline 1978 & 0.789 & 0.888 & 0.701 \\
\hline 1979 & 0.88 & 0.923 & 0.812 \\
\hline 1980 & 0.948 & 0.977 & 0.926 \\
\hline 1981 & 0.845 & 0.995 & 0.841 \\
\hline 1982 & 0.796 & 1.003 & 0.798 \\
\hline 1983 & 0.817 & 1.000 & 0.817 \\
\hline 1984 & 0.835 & 1.002 & 0.837 \\
\hline 1985 & 0.859 & 1.005 & 0.863 \\
\hline 1986 & 0.811 & 0.994 & 0.806 \\
\hline 1987 & 0.795 & 0.980 & 0.779 \\
\hline 1988 & 0.890 & 0.973 & 0.866 \\
\hline 1989 & 0.956 & 0.979 & 0.936 \\
\hline 1990 & 1 & 1.000 & 1.000 \\
\hline
\end{tabular}

\section{Sources:}

$\mathrm{A}_{\mathrm{t}}{ }^{*}=$ estimate of parameter in Equation (5) from the text:

(5) $\quad \ln \mathrm{Q}_{\mathrm{it}}=\mathrm{A}_{\mathrm{i}}+\theta_{\mathrm{i}} \ln \mathrm{L}_{\mathrm{it}}+\left(1-\theta_{\mathrm{i}}\right) \ln \mathrm{e}^{\mathrm{At}} \mathrm{K}_{\mathrm{it}}+\mathrm{v}_{\mathrm{it}}, \quad \mathrm{i}=1 \ldots, \mathrm{n} ; \mathrm{t}=1, \ldots, \mathrm{T}$.

See appendix for details of estimation method.

SNA Deflator $=$ non-residential fixed investment deflator from system of national accounts Japan (1990 basis). Cabinet Office, Government of Japan:

http://www.esri.cao.go.jp/en/sna/qe011-68/gdemenue68.html 
Table 2. Cobb-Douglas Production Functions, AR1 Regression Estimates

$$
\ln \mathrm{Q}_{\mathrm{it}}=\mathrm{a}_{\mathrm{i}}+\theta_{\mathrm{i}} \ln \mathrm{L}_{\mathrm{it}}+\left(1-\theta_{\mathrm{i}}\right) \ln \mathrm{A}_{\mathrm{t}}{ }^{*} \mathrm{~K}_{\mathrm{it}}+\mathrm{v}_{\mathrm{it}} \text {, where } \mathrm{v}_{\mathrm{it}}=\rho \mathrm{v}_{\mathrm{i}, \mathrm{t}-1}+\mathrm{u}_{\mathrm{it}} \text { and } \mathrm{u}_{\mathrm{it}} \sim\left(0, \sigma^{2}\right)
$$

OLS

$\begin{array}{cc}\text { Yule- } & \text { Estimates of } \\ \text { Walker } & \text { Autoregressive } \\ \text { Estimates } & \text { Parameters }\end{array}$

\section{INDUSTRY}

SYNTHETIC FIBERS

MEDICINES

GLASS BULBS FOR USE IN

CATHODE RAY TUBES

WRIST WATCHES

PLASTIC-WORKING

MACHINES

PUMPS

ALUMINUM INGOTS

SPEED CHANGERS

BEARINGS

CELLOPHANE

PIANOS

BOILERS

FISHMEAT SAUSAGE

SANITARY WARE

CHEMICAL SEASONING

SHEET GLASS

STORAGE BATTERIES

ORDINARY STEEL PIPES

AND TUBES

SYNTHETIC RUBBER

RECTIFIERS

\begin{tabular}{rrrrrrrr}
$\begin{array}{c}\text { Durbin- } \\
\text { Watson }\end{array}$ & $\begin{array}{c}\text { Durbin- } \\
\text { Watson }\end{array}$ & \multicolumn{1}{l}{$\boldsymbol{\rho}$ S.E. t Value } & $\boldsymbol{\theta}_{\mathbf{i}}$ & S.E. & t Value \\
1.36 & 1.78 & 0.28 & 0.3 & 0.9 & 0.31 & 0.04 & 7.8 \\
0.3 & 1.49 & 0.8 & 0.12 & 6.9 & 0.33 & 0.03 & 9.7 \\
0.82 & 1.53 & 0.58 & 0.25 & 2.4 & 0.37 & 0.08 & 4.7 \\
& & & & & & & \\
0.63 & 1.69 & 0.64 & 0.16 & 3.9 & 0.37 & 0.05 & 7.9 \\
0.47 & 1.92 & 0.71 & 0.15 & 4.7 & 0.42 & 0.04 & 9.6 \\
& & & & & & & \\
1.43 & 1.84 & 0.28 & 0.18 & 1.5 & 0.42 & 0.03 & 15.2 \\
0.9 & 1.68 & 0.39 & 0.18 & 2.1 & 0.44 & 0.04 & 11.9 \\
0.35 & 1.41 & 0.73 & 0.13 & 5.6 & 0.44 & 0.02 & 18.3 \\
0.62 & 1.36 & 0.42 & 0.17 & 2.4 & 0.45 & 0.03 & 17.1 \\
1.47 & 1.84 & 0.26 & 0.23 & 1.1 & 0.45 & 0.02 & 18.6 \\
0.9 & 1.7 & 0.39 & 0.18 & 2.2 & 0.45 & 0.05 & 9.5 \\
2.12 & 2.01 & -0.07 & 0.19 & -0.4 & 0.46 & 0.03 & 13.5 \\
1.57 & 1.91 & 0.21 & 0.3 & 0.7 & 0.47 & 0.06 & 7.8 \\
1.5 & 1.74 & 0.14 & 0.19 & 0.8 & 0.48 & 0.02 & 23.1 \\
1.63 & 1.63 & 0 & 0.24 & 0 & 0.49 & 0.02 & 21.5 \\
1.27 & 1.77 & 0.22 & 0.19 & 1.2 & 0.49 & 0.02 & 28.3 \\
0.61 & 1.67 & 0.63 & 0.15 & 4.2 & 0.49 & 0.04 & 11.7 \\
0.57 & 1.75 & 0.69 & 0.14 & 5 & 0.5 & 0.04 & 13.1 \\
& & & & & & & \\
1.27 & 1.64 & 0.3 & 0.29 & 1 & 0.5 & 0.06 & 9.1 \\
0.53 & 1.59 & 0.69 & 0.17 & 4 & 0.51 & 0.04 & 11.7
\end{tabular}

Test of Restriction

(Constant returns to scale)
R-Square Value S.E. t Value $\operatorname{Pr}>|t|$

$\begin{array}{rrrr}-0.95 & 0.64 & -1.5 & 0.14 \\ 0.07 & 0.04 & 1.9 & 0.06 \\ 0.06 & 0.04 & 1.8 & 0.08 \\ & & & \\ -0.04 & 0.02 & -1.9 & 0.05 \\ -0.01 & 0.04 & -0.3 & 0.78 \\ & & & \\ -2.02 & 0.63 & -3.2 & 0.00 \\ 0.11 & 0.07 & 1.5 & 0.13 \\ -0.14 & 0.09 & -1.6 & 0.12 \\ 0.02 & 0.04 & 0.5 & 0.62 \\ 0.02 & 0.04 & 0.4 & 0.68 \\ -0.21 & 0.08 & -2.6 & 0.01 \\ 0.03 & 0.06 & 0.5 & 0.64 \\ -0.06 & 0.03 & -2.0 & 0.05 \\ 0.13 & 0.10 & 1.2 & 0.23 \\ 0.09 & 0.12 & 0.8 & 0.47 \\ 0.21 & 0.14 & 1.5 & 0.15 \\ 0.00 & 0.02 & 0.2 & 0.84 \\ -0.16 & 0.05 & -3.1 & 0.00 \\ & & & \\ -0.19 & 0.05 & -4.0 & <.0001 \\ -0.21 & 0.06 & -3.2 & 0.00\end{array}$


OLS $\begin{gathered}\text { Yule- } \\ \text { Walker }\end{gathered}$

Estimates

Parameters

\section{INDUSTRY}

THERMOS BOTTLES

TRACTORS

ELECTRICAL WIRES AND

CABLES

SPINNING MACHINES

ZINC

BICYCLES

COLD-ROLLED STEEL

PLATE

ELECTRICAL COPPER

HAM SAUSAGE

MIXED FEED

PAPER PULP

RECORDS

TIRES AND TUBES FOR

MOTOR VEHICLES

VEGETABLE OIL

POWER TILLERS

EIGHTEEN LITER CANS

ROLLED AND WIRE-DRAWN

COPPER PRODUCTS

ALUMINUM WINDOW

SASHES

COMBED FABRICS

COTTON FABRICS

CHARGING GENERATORS

COKE

CAST IRON PIPES AND TUBES
Durbin- Durbin-

Watson Watson

$\begin{array}{ll}1.5 & 1.77\end{array}$

$\begin{array}{ll}1.31 & 1.57\end{array}$

$0.74 \quad 1.26$

$\begin{array}{ll}1.59 & 1.92\end{array}$

$0.79 \quad 1.66$

$1.15 \quad 1.73$

$1 \quad 1.49$

$0.39 \quad 1.56$

$1.34 \quad 1.52$

$1.27 \quad 1.42$

$0.77 \quad 1.94$

$\begin{array}{ll}1.6 & 1.99\end{array}$

$0.69 \quad 1.63$

$1.95 \quad 1.95$

$1.35 \quad 1.76$

$1.3 \quad 1.65$

$1.03 \quad 1.82$

$1.34 \quad 1.78$

$0.59 \quad 1.47$

$0.91 \quad 1.77$

0.88

0.31

1.12 $\begin{array}{ll}0.29 & 0.23\end{array}$

\section{p S.E. t Value}

$\begin{array}{ll}0.15 & 0.21\end{array}$

$0.61 \quad 0.19$

$\begin{array}{ll}0.19 & 0.24\end{array}$

$0.57 \quad 0.16$

$0.33 \quad 0.18$

$\begin{array}{ll}0.4 & 0.2\end{array}$

$\begin{array}{ll}0.77 & 0.12\end{array}$

$\begin{array}{ll}0.14 & 0.24\end{array}$

$\begin{array}{ll}0.09 & 0.24\end{array}$

$0.57 \quad 0.16$

$0.18 \quad 0.24$

$0.65 \quad 0.15$

$\begin{array}{ll}0 & 0.29\end{array}$

$\begin{array}{ll}0.22 & 0.24\end{array}$

$0.28 \quad 0.18$

$0.41 \quad 0.22$

$0.25 \quad 0.19$

$\begin{array}{ll}0.61 & 0.19\end{array}$

$\begin{array}{ll}0.47 & 0.17\end{array}$

$\begin{array}{ll}0.55 & 0.16\end{array}$

$\begin{array}{ll}0.75 & 0.13\end{array}$

$\begin{array}{ll}0.38 & 0.22\end{array}$
Yule-Walker Estimates

Test of Restriction

(Constant returns to scale) $\theta_{i}$ S.E. t Value

$\begin{array}{ll}0.51 & 0.03\end{array}$

$\begin{array}{ll}0.52 & 0.05\end{array}$

$\begin{array}{ll}0.52 & 0.03\end{array}$

$\begin{array}{ll}0.52 & 0.04\end{array}$

$\begin{array}{ll}0.53 & 0.01\end{array}$

$\begin{array}{ll}0.53 & 0.03\end{array}$

$\begin{array}{ll}0.53 & 0.04\end{array}$

$\begin{array}{ll}0.53 & 0.02\end{array}$

$\begin{array}{ll}0.53 & 0.02\end{array}$

$\begin{array}{ll}0.53 & 0.04\end{array}$

$\begin{array}{ll}0.53 & 0.05\end{array}$

$\begin{array}{ll}0.53 & 0.03\end{array}$

$\begin{array}{ll}0.53 & 0.05\end{array}$

$\begin{array}{ll}0.54 & 0.02\end{array}$

$\begin{array}{ll}0.55 & 0.01\end{array}$

$\begin{array}{ll}0.55 & 0.03\end{array}$

$\begin{array}{ll}0.56 & 0.01\end{array}$

$\begin{array}{ll}0.56 & 0.04\end{array}$

$\begin{array}{ll}0.56 & 0.02\end{array}$

$\begin{array}{ll}0.57 & 0.04\end{array}$

$0.58 \quad 0.05$

$0.59 \quad 0.04$

10.8
16.6
10.3

15.3

10.5

13.9

38

21

R-Square

\subsection{5}

0.98

0.96

0.93

0.86

0.99

0.96

0.91

0.99

0.97

0.86

0.96

0.98

$$
10.8
$$$$
48.2
$$$$
38.4
$$

$$
14.5
$$

0.74

0.98

0.99

0.96

0.99
Value S.E. t Value $\operatorname{Pr}>|\mathbf{t}|$

$\begin{array}{ll}0.10 & 0.10\end{array}$

$\begin{array}{llll}-0.17 & 0.09 & -2.0 & 0.04\end{array}$

$\begin{array}{llll}-0.01 & 0.02 & -0.3 & 0.75\end{array}$

$\begin{array}{llll}-0.10 & 0.07 & -1.5 & 0.13\end{array}$

$\begin{array}{llll}0.02 & 0.02 & 1.6 & 0.12\end{array}$

$\begin{array}{llll}-0.06 & 0.08 & -0.8 & 0.47\end{array}$

$\begin{array}{llll}-0.37 & 0.12 & -3.2 & 0.00\end{array}$

$\begin{array}{llll}-0.04 & 0.04 & -1.0 & 0.32\end{array}$

$\begin{array}{llll}-0.09 & 0.04 & -2.5 & 0.01\end{array}$

$0.200 .06 \quad 3.6<.0001$

$\begin{array}{llll}0.05 & 0.02 & 2.3 & 0.02\end{array}$

$\begin{array}{llll}-0.09 & 0.12 & -0.8 & 0.48\end{array}$

$\begin{array}{llll}-0.12 & 0.10 & -1.3 & 0.21\end{array}$

$\begin{array}{llll}0.00 & 0.01 & 0.2 & 0.83\end{array}$

$\begin{array}{llll}0.04 & 0.02 & 1.9 & 0.05\end{array}$

$\begin{array}{llll}0.00 & 0.01 & -0.1 & 0.96\end{array}$

$0.04 \quad 0.03$

$1.3 \quad 0.19$

$\begin{array}{llll}-0.09 & 0.04 & -2.5 & 0.01\end{array}$

$\begin{array}{llll}0.01 & 0.01 & 0.9 & 0.38\end{array}$

$\begin{array}{llll}-0.09 & 0.10 & -0.8 & 0.42\end{array}$

$\begin{array}{llll}0.06 & 0.03 & 2.1 & 0.04\end{array}$

$\begin{array}{llll}-0.51 & 0.30 & -1.7 & 0.08\end{array}$ 
OLS Yule-

Walker

Estimates

Parameters
Yule-W alker Estimates

Test of Restriction

(Constant returns to scale)

\section{INDUSTRY}

GRINDING STONES

BEER

GALVANIZED

COTTON YARN

GLASS CONTAINERS FOR

BEVERAGES

PAINTS

VINYL CHLORIDE RESIN

CEMENT

CAUSTIC SODA

PETROLEUM PRODUCTS

PRINTING MACHINES

PRINTING INK

TILE

CANNED SEAFOOD

FISHING NETS

SUGAR

DISSOLVING PULP

FIREPROOF BROOKS

CALCIUM CARBIDE

MANMADE-GRAPHITE

ELECTRODES

SAKE

VALVE COCKS

MEN'S SHOES

RAW SILK

SOY

WHEAT FLOUR
Durbin- Durbin-

Watson Watson

$\begin{array}{ll}0.93 & 1.98 \\ 1.34 & 1.92\end{array}$

$1.48 \quad 1.99$

$0.56 \quad 1.99$
0.68

$0.68 \quad 1.46$

$0.64 \quad 1.62$

$1.68 \quad 1.73$

$0.55 \quad 1.32$

$0.57 \quad 1.6$

$\begin{array}{rr}0.3 & 1.61 \\ 0.85 & 1.97\end{array}$

$\begin{array}{ll}0.85 & 1.97\end{array}$

$\begin{array}{ll}0.53 & 1.7\end{array}$

$0.45 \quad 1.63$

$1.05 \quad 1.72$

$0.3 \quad 1.33$

$1.12 \quad 1.71$

$0.77 \quad 1.36$

$1.56 \quad 1.61$

$0.68 \quad 1.13$

$1.97 \quad 1.96$

$\begin{array}{ll}1.2 & 1.88\end{array}$

$0.84 \quad 1.83$

$1.31 \quad 1.52$

$0.87 \quad 1.58$

$0.48 \quad 1.61$

$0.81 \quad 2.35$

\section{p S.E. t Value}

$0.53 \quad 0.16$

$\begin{array}{ll}0.33 & 0.18\end{array}$

$\begin{array}{ll}0.25 & 0.19\end{array}$

$0.64 \quad 0.15$

$0.61 \quad 0.15$

$\begin{array}{ll}0.63 & 0.15\end{array}$

$0.03 \quad 0.3$

$0.61 \quad 0.15$

$\begin{array}{ll}0.7 & 0.14\end{array}$

$\begin{array}{ll}0.72 \quad 0.13 \\ 0.57 & 0.2\end{array}$

$\begin{array}{ll}0.57 & 0.2\end{array}$

$0.69 \quad 0.14$

$\begin{array}{ll}0.74 & 0.13\end{array}$

$0.37 \quad 0.18$

$0.78 \quad 0.12$

$\begin{array}{ll}0.41 & 0.22\end{array}$

$\begin{array}{ll}0.52 & 0.21\end{array}$

$\begin{array}{ll}0.04 & 0.24\end{array}$

$\begin{array}{ll}0.56 & 0.2\end{array}$

$\begin{array}{ll}-0.01 & 0.22\end{array}$

$\begin{array}{ll}0.33 & 0.18\end{array}$

$\begin{array}{ll}0.53 & 0.21\end{array}$

$\begin{array}{ll}0.11 & 0.24\end{array}$

$\begin{array}{ll}0.42 & 0.22\end{array}$

$\begin{array}{lll}0.68 & 0.14\end{array}$

$0.55 \quad 0.16$ $\theta_{i} \quad$ S.E. t Value

$\begin{array}{ll}0.59 & 0.03\end{array}$

$\begin{array}{ll}0.6 & 0.01\end{array}$

$\begin{array}{ll}0.6 & 0.02\end{array}$

$\begin{array}{ll}0.61 & 0.04\end{array}$

$0.61 \quad 0.02$

$\begin{array}{ll}0.61 & 0.02\end{array}$

$\begin{array}{ll}0.61 & 0.04\end{array}$

$\begin{array}{ll}0.62 & 0.02\end{array}$

$\begin{array}{ll}0.63 & 0.03\end{array}$

$\begin{array}{ll}0.63 & 0.04\end{array}$

$\begin{array}{ll}0.63 & 0.02\end{array}$

$\begin{array}{ll}0.65 & 0.02\end{array}$

$\begin{array}{ll}0.65 & 0.03\end{array}$

$\begin{array}{ll}0.66 & 0.02\end{array}$

$\begin{array}{ll}0.66 & 0.03\end{array}$

$0.66 \quad 0.03$

$\begin{array}{ll}0.67 & 0.03\end{array}$

$\begin{array}{ll}0.68 & 0.02\end{array}$

$\begin{array}{ll}0.69 & 0.04\end{array}$

$\begin{array}{ll}0.69 & 0.02\end{array}$

$\begin{array}{ll}0.69 & 0.02 \\ 0.69 & 0.03\end{array}$

$\begin{array}{lll}0.69 & 0.03\end{array}$

$\begin{array}{ll}0.71 & 0.01\end{array}$

$\begin{array}{ll}0.71 & 0.02\end{array}$

$\begin{array}{ll}0.71 & 0.02\end{array}$

$\begin{array}{ll}0.73 & 0.02\end{array}$
R-Square

0.93

0.98

0.89

0.96

0.99

0.91

0.95

0.91

0.98

0.98

0.99

0.97

0.86

0.95

0.91

0.93

0.89

0.92

0.78

0.97

0.98

0.52

0.89

0.86
Value S.E. t Value $\operatorname{Pr}>|t|$

0.090 .05

$\begin{array}{llll}-0.03 & 0.01 & -1.9 & 0.06\end{array}$

$\begin{array}{llll}0.00 & 0.03 & 0.0 & 0.97\end{array}$

$\begin{array}{lll}-0.47 & 0.12 & -3.8<.0001\end{array}$

\section{$\begin{array}{llll}-0.09 & 0.03 & -2.7 & 0.00\end{array}$}

$\begin{array}{llll}0.22 & 0.19 & 1.1 & 0.27\end{array}$

$\begin{array}{llll}0.08 & 0.04 & 2.3 & 0.02\end{array}$

$\begin{array}{llll}0.02 & 0.02 & 1.2 & 0.22\end{array}$

$\begin{array}{llll}0.07 & 0.05 & 1.4 & 0.15\end{array}$

$\begin{array}{llll}-0.10 & 0.06 & -1.6 & 0.12\end{array}$

$\begin{array}{llll}-0.17 & 0.08 & -2.3 & 0.02\end{array}$

$\begin{array}{llll}-0.03 & 0.01 & -2.0 & 0.04\end{array}$

$\begin{array}{llll}-0.01 & 0.02 & -0.5 & 0.63\end{array}$

$\begin{array}{llll}0.18 & 0.11 & 1.7 & 0.08\end{array}$

$\begin{array}{llll}0.01 & 0.04 & 0.3 & 0.77\end{array}$

$\begin{array}{llll}-0.03 & 0.02 & -1.8 & 0.07\end{array}$

$\begin{array}{llll}-0.07 & 0.04 & -1.9 & 0.05\end{array}$

$\begin{array}{llll}-0.06 & 0.08 & -0.8 & 0.48\end{array}$

$\begin{array}{llll}0.12 & 0.18 & 0.6 & 0.54\end{array}$

$\begin{array}{llll}-0.02 & 0.03 & -0.6 & 0.56\end{array}$

$\begin{array}{llll}-0.06 & 0.03 & -2.3 & 0.02\end{array}$

$\begin{array}{llll}0.09 & 0.05 & 1.7 & 0.09\end{array}$

$\begin{array}{llll}0.01 & 0.03 & 0.5 & 0.61\end{array}$

$\begin{array}{llll}0.03 & 0.03 & 1.3 & 0.22\end{array}$

$\begin{array}{llll}0.11 & 0.06 & 1.8 & 0.08\end{array}$ 


\section{OLS Yule-}

Walker

Estimates

Estimates of

Autoregressive

Parameters

\section{INDUSTRY}

MISO

WORSTED YARN

JUTE YARN

WEAVING MACHINES

BRIQUETTES
Durbin- Durbin-

Watson Watson

mean

$\begin{array}{rrrrrrrrr} & 0.81 & 2.01 & 0.56 & 0.16 & 3.5 & 0.74 & 0.01 & 63.1 \\ & 0.89 & 1.92 & 0.53 & 0.16 & 3.2 & 0.74 & 0.05 & 13.9 \\ & 1.95 & 1.96 & -0.21 & 0.28 & -0.7 & 0.77 & 0.03 & 24.1 \\ & 2.01 & 1.91 & -0.06 & 0.24 & -0.2 & 0.78 & 0.06 & 12.9 \\ & 0.76 & 2.11 & 0.55 & 0.2 & 2.8 & 0.95 & 0.04 & 24.3 \\ \text { mean } & 1.02 & 1.72 & 0.42 & 0.19 & 2.6 & 0.57 & 0.03 & 22.1 \\ \text { s.d. } & 0.47 & 0.22 & 0.25 & 0.05 & 1.9 & 0.11 & 0.01 & 12.2\end{array}$

Yule-Walker Estimates

Test of Restriction

(Constant returns to scale)

\section{R-Square}

$$
0.97
$$

0.78

0.88

0.14

0.99

0.91

0.14
Value S.E. $t$ Value $\operatorname{Pr}>|t|$

$\begin{array}{rrrr}-0.16 & 0.24 & -0.7 & 0.52 \\ -0.05 & 0.02 & -2.3 & 0.02 \\ -0.27 & 0.14 & -1.9 & 0.05 \\ -0.02 & 0.04 & -0.5 & 0.67 \\ -0.33 & 0.17 & -2.0 & 0.04 \\ -0.07 & & -0.4 & 0.26 \\ 0.29 & & 1.8 & 0.28\end{array}$


Table 3. Regression analysis of Herfindahl index ; two-way random effects.

$$
\mathrm{H}_{\mathrm{it}}=\beta_{0}+\beta_{1} \mathrm{~m}_{\mathrm{it}}+\beta_{2} \theta_{\mathrm{i}}^{*}+\beta_{3} \ln \mathrm{L}_{\mathrm{it}}+\varepsilon_{\mathrm{i}}+\varepsilon_{\mathrm{t}}+v_{\mathrm{it}}
$$

$\begin{array}{lrrrr}\text { Variable } & \text { Estimate } & \begin{array}{c}\text { Standard } \\ \text { Error }\end{array} & \text { t value } & \text { Pr }>|\mathbf{t}| \\ & & & & \\ \text { Intercept } & 0.66 & 0.08 & 8.3 & <.0001 \\ \theta_{\mathrm{i}}{ }^{*} & -0.41 & 0.12 & -3.3 & 0.001 \\ \operatorname{lnL}_{\mathrm{it}} & -0.03 & 0.00 & -8.7 & <.0001 \\ \mathrm{~m}_{\mathrm{it}} & 0.11 & 0.02 & 5.9 & <.0001\end{array}$

R-Square $\quad 0.068$

Number of Cross Sections $\quad 74$

Time Series Length $\quad 30$

Variance Component for Cross Sections $\quad 0.014$

Variance Component for Time Series $\quad 0.000$

Variance Component for Error $\quad 0.002$ 
Table 4. Estimates of average rate of technical advance in each industry, 1961-1990.

\section{Estimated OLS trend}

$$
\mathrm{v}_{\mathrm{it}}^{*}=\gamma_{0 \mathrm{i}}+\gamma_{1 \mathrm{i}} \mathrm{t}+\varepsilon_{\mathrm{it}}, \quad \mathrm{i}=1, \ldots, \mathrm{n}
$$

where $\mathrm{v}_{\mathrm{it}}{ }^{*}$ is the estimated error term in the regression equations reported in Table 2 above. The table also reports average Herfindahl Index $\bar{H}_{i}$ and average price-cost margin $\overline{\mathrm{m}}_{\mathrm{i}}$.

INDUSTRY
GLASS BULBS FOR USE IN CATHODE RAY TUBES
COTTON YARN
ELECTRICAL COPPER
CALCIUM CARBIDE
MEDICINES
WRIST WATCHES
RECORDS
VALVE COCKS
RAW SILK
CAUSTIC SODA
JUTE YARN
PAPER PULP
COTTON FABRICS
GLASS CONTAINERS FOR BEVERAGES
FISHMEAT SAUSAGE
WEAVING MACHINES
ORDINARY STEEL PIPES AND TUBES
SOY
WORSTED YARN
ALUMINUM INGOTS
PIANOS
TILE
GALVANIZED
CHEMICAL SEASONING
TRACTORS
CEMENT

\begin{tabular}{rrrr} 
n & \multicolumn{1}{l}{$\boldsymbol{\gamma}_{1 \mathbf{i}} *$} & \multicolumn{1}{l}{$\overline{\mathbf{H}}_{\mathbf{i}}$} & \multicolumn{1}{c}{$\overline{\mathbf{m}}_{\mathbf{i}}$} \\
& & & \\
14 & $1.35 \%$ & 0.460 & $1.2 \%$ \\
30 & $0.99 \%$ & 0.034 & $3.2 \%$ \\
30 & $0.91 \%$ & 0.181 & $8.8 \%$ \\
20 & $0.89 \%$ & 0.252 & $10.0 \%$ \\
28 & $0.87 \%$ & 0.025 & $30.1 \%$ \\
30 & $0.75 \%$ & 0.382 & $-13.9 \%$ \\
10 & $0.72 \%$ & 0.101 & $25.6 \%$ \\
10 & $0.72 \%$ & 0.037 & $16.1 \%$ \\
20 & $0.58 \%$ & 0.030 & $5.2 \%$ \\
30 & $0.57 \%$ & 0.047 & $17.6 \%$ \\
10 & $0.53 \%$ & 0.396 & $12.7 \%$ \\
30 & $0.52 \%$ & 0.068 & $10.8 \%$ \\
30 & $0.40 \%$ & 0.007 & $8.1 \%$ \\
24 & $0.40 \%$ & 0.174 & $19.3 \%$ \\
14 & $0.39 \%$ & 0.144 & $6.3 \%$ \\
20 & $0.38 \%$ & 0.133 & $19.6 \%$ \\
30 & $0.33 \%$ & 0.128 & $10.7 \%$ \\
30 & $0.32 \%$ & 0.074 & $23.2 \%$ \\
30 & $0.29 \%$ & 0.037 & $8.4 \%$ \\
30 & $0.29 \%$ & 0.353 & $-11.9 \%$ \\
28 & $0.28 \%$ & 0.464 & $7.2 \%$ \\
24 & $0.25 \%$ & 0.090 & $17.0 \%$ \\
30 & $0.24 \%$ & 0.146 & $5.6 \%$ \\
14 & $0.23 \%$ & 0.352 & $9.3 \%$ \\
20 & $0.21 \%$ & 0.292 & $14.1 \%$ \\
30 & $0.19 \%$ & 0.086 & $27.6 \%$
\end{tabular}




\section{INDUSTRY}

SHEET GLASS

PLASTIC-WORKING MACHINES

SANITARY WARE

MANMADE-GRAPHITE ELECTRODES

CAST IRON PIPES AND TUBES

COMBED FABRICS

TIRES AND TUBES FOR MOTOR VEHICLES

BICYCLES

SUGAR

ALUMINUM WINDOW SASHES

BEER

MIXED FEED

SYNTHETIC FIBERS

EIGHTEEN LITER CANS

HAM SAUSAGE

MEN'S SHOES

POWER TILLERS

ROLLED AND WIRE-DRAWN COPPER PRODUCTS

STORAGE BATTERIES

FIREPROOF BROOKS

MISO

CANNED SEAFOOD

COLD-ROLLED STEEL PLATE

CELLOPHANE

SPINNING MACHINES

VEGETABLE OIL

BEARINGS

PAINTS

SAKE

GRINDING STONES

WHEAT FLOUR

BRIQUETTES

PRINTING INK

CHARGING GENERATORS $\gamma_{1 \mathrm{i}} * \quad \overline{\mathbf{H}}_{\mathrm{i}} \quad \overline{\mathbf{m}}_{\mathrm{i}}$

$0.17 \% \quad 0.388 \quad 45.4 \%$

$0.16 \% \quad 0.110 \quad-0.1 \%$

$0.15 \% \quad 0.442 \quad 7.9 \%$

$0.13 \% \quad 0.183 \quad 21.9 \%$

$0.12 \% \quad 0.383 \quad 26.8 \%$

$0.12 \% \quad 0.012 \quad 12.7 \%$

$0.12 \% \quad 0.288 \quad 14.7 \%$

$0.11 \% \quad 0.062 \quad 10.9 \%$

$0.10 \% \quad 0.065 \quad 7.9 \%$

$0.09 \% \quad 0.157 \quad 7.0 \%$

$0.08 \% \quad 0.394 \quad 6.1 \%$

$0.08 \% \quad 0.107 \quad 8.1 \%$

$0.08 \% \quad 0.127 \quad 26.3 \%$

$0.08 \% \quad 0.041 \quad 16.0 \%$

$0.07 \% \quad 0.070 \quad 8.6 \%$

$0.04 \% \quad 0.037 \quad 13.5 \%$

$0.04 \% \quad 0.148 \quad 15.2 \%$

$0.03 \% \quad 0.039 \quad 3.5 \%$

$0.03 \% \quad 0.221 \quad 16.2 \%$

$0.02 \% \quad 0.050 \quad 9.2 \%$

$0.00 \% \quad 0.017 \quad 26.9 \%$

$0.00 \% \quad 0.060 \quad 9.0 \%$

$-0.04 \% \quad 0.176 \quad 5.7 \%$

$-0.05 \% \quad 0.208 \quad 6.1 \%$

$-0.07 \% \quad 0.244 \quad 1.5 \%$

$-0.08 \% \quad 0.096 \quad 15.2 \%$

$-0.09 \% \quad 0.209 \quad 2.5 \%$

$-0.14 \% \quad 0.057 \quad 20.5 \%$

$-0.14 \% \quad 0.005 \quad 20.0 \%$

$-0.15 \% \quad 0.069 \quad 14.2 \%$

$-0.16 \% \quad 0.147 \quad 14.5 \%$

$-0.20 \% \quad 0.080 \quad 15.0 \%$

$-0.21 \% \quad 0.137 \quad 7.6 \%$

$-0.22 \% \quad 0.322 \quad 2.8 \%$ 


\section{INDUSTRY}

THERMOS BOTTLES

ZINC

SYNTHETIC RUBBER

VINYL CHLORIDE RESIN

RECTIFIERS

PUMPS

PRINTING MACHINES

SPEED CHANGERS

DISSOLVING PULP

ELECTRICAL WIRES AND CABLES

BOILERS

FISHING NETS

PETROLEUM PRODUCTS

$$
\text { COKE }
$$

$\overline{\mathbf{H}}_{\mathrm{i}} \quad \overline{\mathbf{m}}_{\mathrm{i}}$

$-0.22 \% \quad 0.250 \quad 15.0 \%$

$-0.23 \% \quad 0.180 \quad 5.3 \%$

$-0.23 \% \quad 0.322 \quad 34.0 \%$

$-0.27 \% \quad 0.059 \quad 8.0 \%$

$-0.27 \% \quad 0.111 \quad 3.7 \%$

$-0.31 \% \quad 0.077 \quad 1.5 \%$

$-0.32 \% \quad 0.114 \quad 12.8 \%$

$-0.33 \% \quad 0.073 \quad-3.1 \%$

$-0.35 \% \quad 0.299 \quad 8.6 \%$

$-0.45 \% \quad 0.077 \quad 6.3 \%$

$-0.47 \% \quad 0.274 \quad 4.4 \%$

$-0.49 \% \quad 0.050 \quad 10.0 \%$

$-0.65 \% \quad 0.065 \quad 8.6 \%$

$-0.87 \% \quad 0.148 \quad 3.8 \%$

mean

$0.11 \% \quad 0.159 \quad 11.5 \%$

$0.40 \% \quad 0.126 \quad 9.5 \%$ 
Table 5. Regression analysis of average rate of technical advance

Dependent variable $=\gamma_{i 1}{ }^{*}$, trend rate of growth in technical advance from regression in Table 3 .

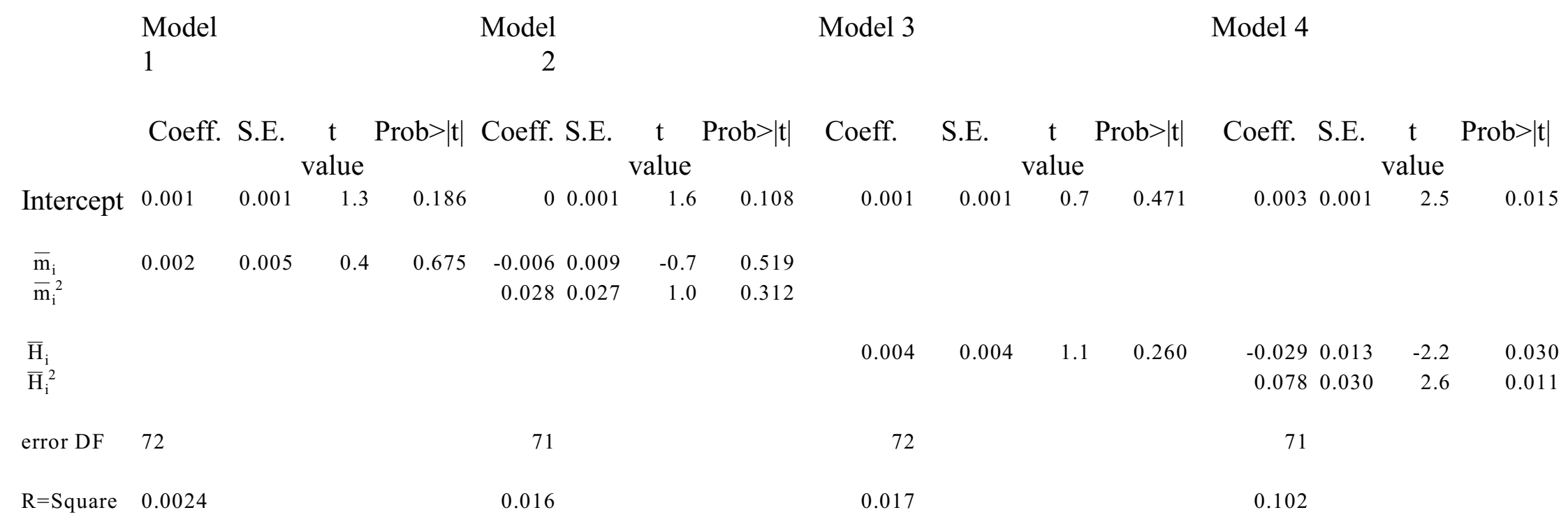


Figure 1. Implicit Deflator of Capital, Adjusted for Inflation and Not, 1990=1

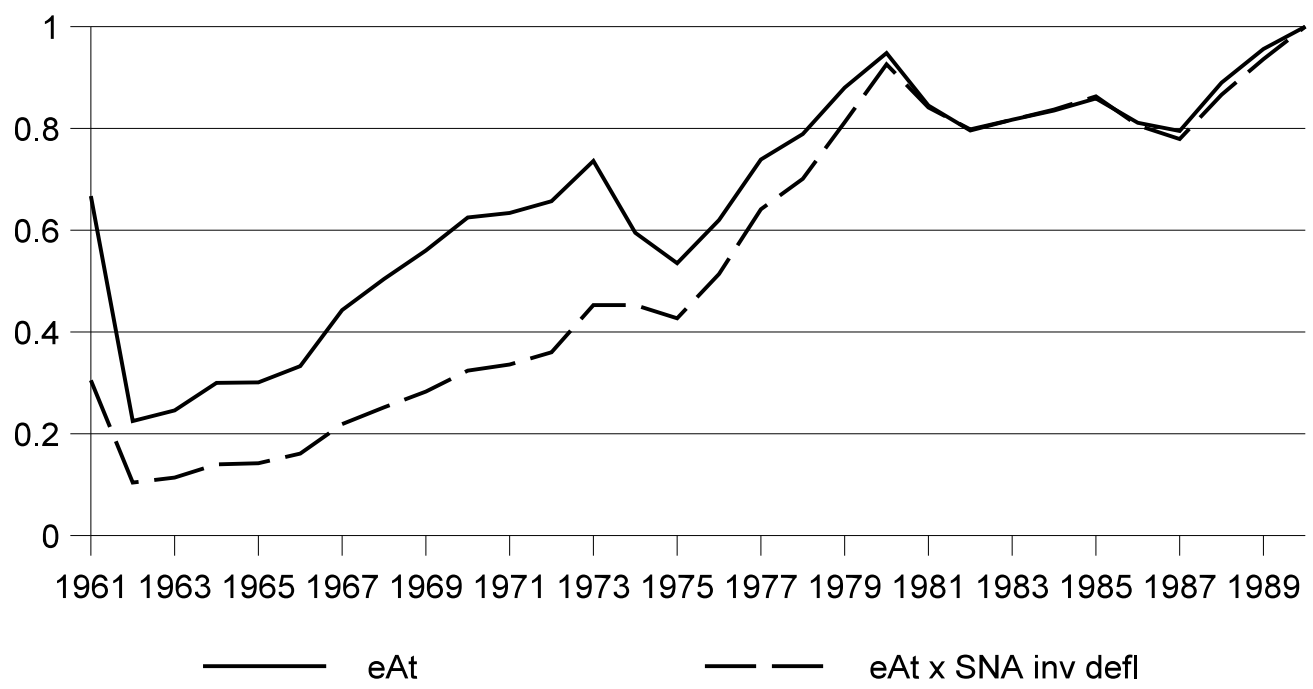

Note:

$\mathrm{e}^{\mathrm{At}}=$ efficiency units of capital per nominal unit based on estimates

$\mathrm{e}^{\mathrm{At}} \times$ SNA investment deflator $=$ efficiency units of capital per physical unit 
Figure 2. Plot of regression estimate in Table 6, Model 4.

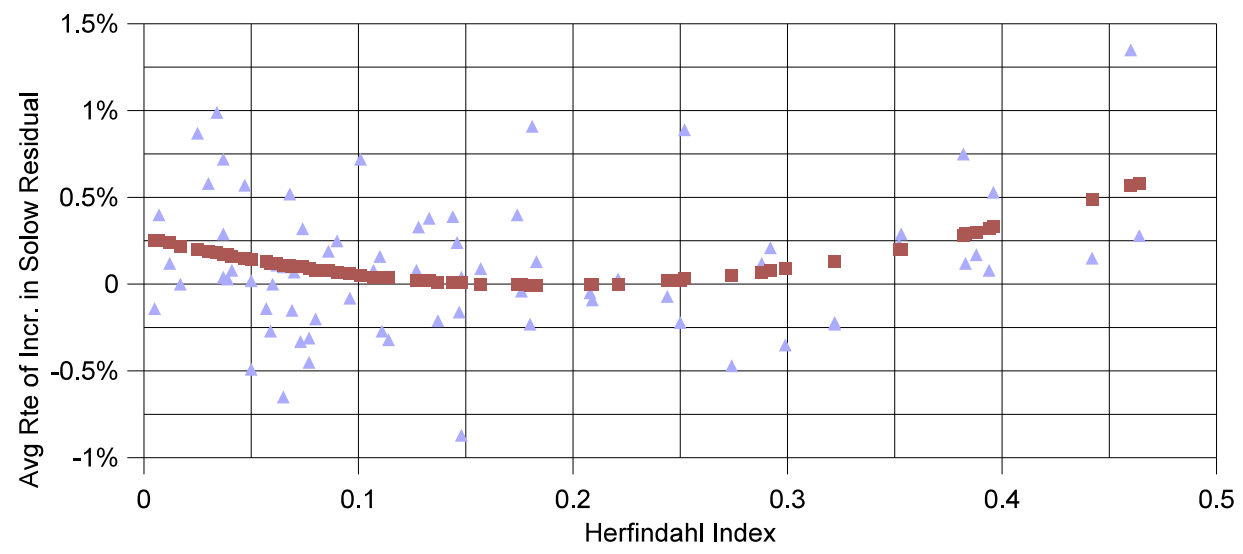

